(Seismological Research Letters, July/August 2005, Vol.76 (4):466-471)

\title{
Comment on "How Can Seismic Hazard around the New Madrid Seismic Zone Be Similar to that in California?" by Arthur Frankel
}

\author{
Zhenming Wang, Baoping Shi, and John D. Kiefer \\ Kentucky Geological Survey, University of Kentucky, Lexington, Kentucky 40506
}

A recent paper in the September/October 2004 issue of Seismological Research Letters, "How Can Seismic Hazard around the New Madrid Seismic Zone Be Similar to That in California?," by Arthur Frankel, concludes "I have demonstrated how probabilistic seismic hazard for New Madrid can be greater than that at San Francisco at low probabilities for PGA and similar at low probabilities for $5 \mathrm{~Hz}$ S.A. By low probabilities, I mean annual probabilities less than the reciprocal of the return time of the New Madrid characteristic source, that is, $1 / 500$. This is a consequence of the higher ground motions, for PGA and $5 \mathrm{~Hz}$ S.A. (and other high-frequency measures), expected for large New Madrid characteristic earthquakes compared to San Andreas earthquakes with similar magnitudes." However, his conclusion is not necessary true and confusing. The fundamental differences in assessing seismic hazard between San Francisco and the New Madrid seismic zone are the uncertainties, especially the uncertainties associated with ground motion attenuation relationship. The larger ground motion uncertainties in both median and its standard deviation derive higher hazard in the New Madrid area. The larger standard deviation, in particular, derives higher hazard at low annual probabilities of exceedance. Moreover, Frankel also equated the hazard (annual probability of exceedance) defined in probabilistic seismic hazard analysis (PSHA) with the average recurrence rate defined in engineering risk analysis. There is a fundamental difference in defining risk between PSHA and the engineering risk analysis. The risks, 10, 5, and 2\% probability of exceedance (PE) in 50 years, defined in PSHA are not interchangeable with those defined in the engineering risk analysis. Hence, though Frankel's stated intention was to improve understanding of PSHA among nonpractitioners, the paper may cause more confusion and problems for the users of the US Geological Survey national seismic hazard maps.

\section{New Madrid vs. San Francisco}

"Uncertainty in seismic hazard estimates is a fact of life, even in California where seismic hazard input parameters are better known than in the CUS (the central United States)" (Cramer, 2001). The fundamental differences in assessing seismic hazard between San Francisco and the New Madrid area are the uncertainties, including source, earthquake magnitude and frequency, and ground motion attenuation. The ground motion attenuation relationships, in particular, are significantly different. The attenuation relationships for California are based on real observations, e.g., Abrahamson and Silva (1997), Boore et al. (1997), Campbell and Bozorgnia (2003), and Sadigh et al. (1997). In 
contract, there are at least thirteen ground motion attenuation relationships available in the central US (EPRI, 2003), and all these relationships were developed from theoretical models with or without calibrations with limited ground motion records from small earthquakes $(<\mathrm{M} 6.0)$. This results in large ground motion uncertainties in both median and its standard deviation for the New Madrid seismic zone. As shown by Frankel (2004), the median ground motions for California vary only slightly between the attenuation relationships. For example, PGA ranges from 0.30 to $0.38 \mathrm{~g}$ between four attenuation relationships for an M7.8 earthquake at $15 \mathrm{~km}$ in San Francisco. In contract, Table 1 lists the median PGA for an M7.7 earthquake at $15 \mathrm{~km}$ in the New Madrid seismic zone from five attenuation relationships. The range of the median PGA is between 0.69 and $1.20 \mathrm{~g}$. However, the predicted median ground motions themselves are uncertain because they are all based on the theoretical models. The theoretical models also predict higher standard deviations in the central US, 0.6-0.8 (EPRI, 2003).

Table 1. Median ground motions for an M7.7 New Madrid earthquake from several attenuations relationships at $15 \mathrm{~km}$ for a hard-rock site.

\begin{tabular}{|c|c|c|c|c|c|}
\hline & $\begin{array}{c}\text { Frankel et al. } \\
(1996)\end{array}$ & $\begin{array}{c}\text { Toro et al. } \\
(1997)\end{array}$ & $\begin{array}{c}\text { Atkinson and } \\
\text { Boore (1995) }\end{array}$ & $\begin{array}{c}\text { Campbell } \\
(2003)\end{array}$ & $\begin{array}{c}\text { Somerville et al. } \\
(2001)\end{array}$ \\
\hline PGA (g) & 1.20 & 0.90 & 0.90 & 0.91 & 0.69 \\
\hline
\end{tabular}

As modeled by Harmsen et al. (1999), Frankel et al. (2002), and Frankel (2004), seismic hazard is predominantly contributed by the large earthquakes $(7.0<\mathrm{M}<8.0)$ in the New Madrid seismic zone. The large earthquakes in the New Madrid seismic zone have been considered as the characteristic events in PSHA for the New Madrid area (Frankel et al., 1996 and 2002; Toro and Silva, 2001; Frankel, 2004). For such characteristic seismic sources, the seismic hazard (annual probability of exceedance) is equal to

$$
\gamma(y)=\frac{1}{T_{C}} P[Y \geq y]
$$

where $T_{C}$ is the average recurrence time of the characteristic earthquake, $P(Y \geq y)$ is the probability that ground motion, $Y$, will be equal or greater than $y$ at a site and determined by the ground motion attenuation relationship. The attenuation relationship was used to describe the randomness of ground motions due to the spatial distribution of the observations and sources (Campbell, 1981 and 2003; Joyner and Boore, 1982). There are at least thirteen attenuation relationships are available in the central and eastern US (EPRI, 2003) and there is no unique way on how to use them (SSHAC, 1997). A logictree with the assigned weights is commonly used to combine some or all of the attenuation relationships in PSHA (Cramer, 2001; EPRI, 2003). Although the logic-tree could be complicated, a mean value can always be obtained (Cramer, 2001; Frankel et al., 2002). For example, a logic tree with the assigned weights of M7.3 (0.15 wt), M7.5 (0.2 wt), M7.7 (0.5 wt), M8.0 (0.15 wt) was used in the 2002 USGS hazard maps for New Madrid characteristic earthquake. Frankel et al. (2002) found that incorporating this logic tree produced essentially the same hazard as giving full weight to the M 7.7 scenario. 
For ease of comparison and understanding, we use Sommerville et al. (2001) attenuation relationship with a standard deviation of 0.6 to construct a hazard curve for the New Madrid characteristic earthquake (M7.7) with an average recurrence time of 500 years (Fig. 1). Figure 1 shows the steps to construct seismic hazard curve for peak ground acceleration (PGA) at a site $40 \mathrm{~km}$ from the source. The hazard (annual probability of exceedance) is equal to the recurrence rate of the characteristic earthquake $(0.002$ or $1 / 500$ yr.) times the probability that PGA exceeds a certain value. For example, the annual probability of exceedance, 0.002 , is equal to the recurrence rate, 0.002 , times the probability, 1.0 , that PGA exceeds $0.05 \mathrm{~g}$. The annual probability of exceedance, 0.001 , is equal to the recurrence rate, 0.002 , times the probability, 0.5 , that PGA exceeds $0.36 \mathrm{~g}$ (median). The annual probability of exceedance, 0.0004 , is equal to the recurrence rate, 0.002 , times the probability, 0.2 , that PGA exceeds $0.59 \mathrm{~g}$. These demonstrate that the true meaning of the hazard: the PGAs, $0.05,0.36$, and $0.59 \mathrm{~g}$, will have 100,50 , and $20 \%$ being exceeded or 0,50 , and $80 \%$ confidence levels, respectively, at a site $40 \mathrm{~km}$ from the source, if the characteristic earthquake occurs once every 500 years on average.
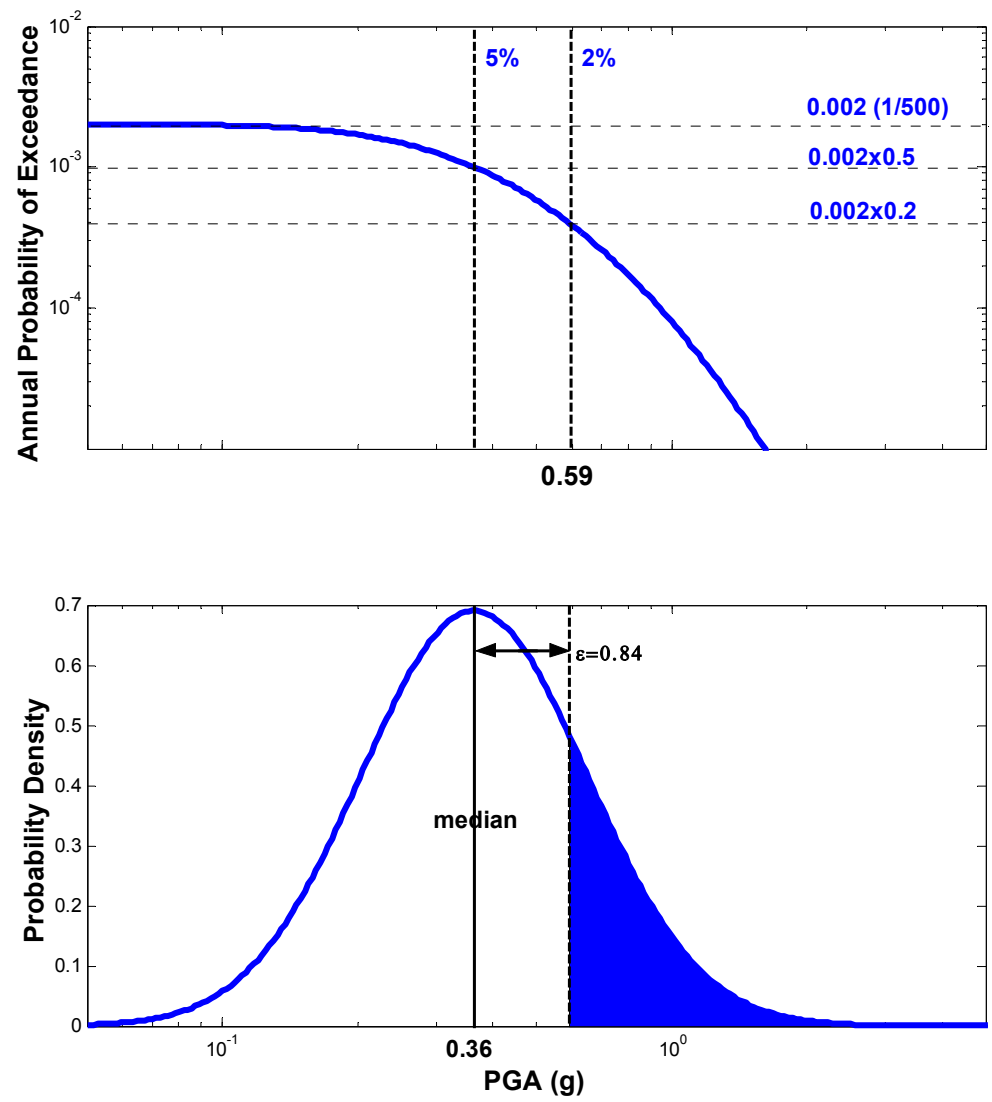

Figure 1. Hazard curve at a site $40 \mathrm{~km}$ from the source for a characteristic earthquake of M7.7 with a recurrence time of 500 years in the New Madrid seismic zone. The median ground motion $(\mu)$ is $0.36 \mathrm{~g}$, and the standard deviation $\left(\sigma_{\ln }\right)$ is $0.60 . \varepsilon=(\ln y-\ln \mu) / \sigma_{\ln }$.

In current PSHA, the annual probability of exceedance is often expressed as its reciprocal, $1 / \gamma$, the return period. For example, the annual probabilities of exceedance, $0.002,0.001$, and 0.0004 , are expressed as the return periods of 500,1,000, and 2,500 
years, respectively. In the New Madrid area, the return period is equal to the recurrence interval of the characteristic earthquake, 500 years, divided by the probability that PGA exceeds the corresponding values (Fig. 1). Thus, the return periods of 500, 1,000, and 2,500 years are equal to the recurrence interval, 500 years, divided by the probabilities, $1.0,0.5$, and 0.2 , that PGA exceeds $0.05,0.36$, and $0.59 \mathrm{~g}$, respectively (Fig. 1). In another words, the return period is a statistical inference from the ground motion (spatial) randomness, not a time domain measurement of the characteristic earthquake. The time domain measurement of the characteristic earthquake is only one, about once every 500 years on average in the New Madrid seismic zone (Tuttle et al., 2002).

Figure 1 also shows that the hazard (annual probability of exceedance) is not only determined by the median ground motion, but also by its standard deviation. Most importantly, the hazard at low annual probability of exceedance, less than $0.002(1 / 500)$, is largely determined by the standard deviation. As noted by Frankel (2004), the rate of hazard curve change at the low annual probability of exceedance is related to the standard deviation. Figure 2 shows a comparison of the hazard curves for median PGAs of 1.20 and $0.69 \mathrm{~g}$ (Table 1) and standard deviations of 0.38 and 0.7 . Figure 2 demonstrates the effects of the median and its standard deviation. Higher median PGA implies higher hazard (shifts the curve to right), whereas a higher standard deviation implies higher hazard (increase the rate of hazard curve) at low annual probability of exceedance $(<0.001)$.

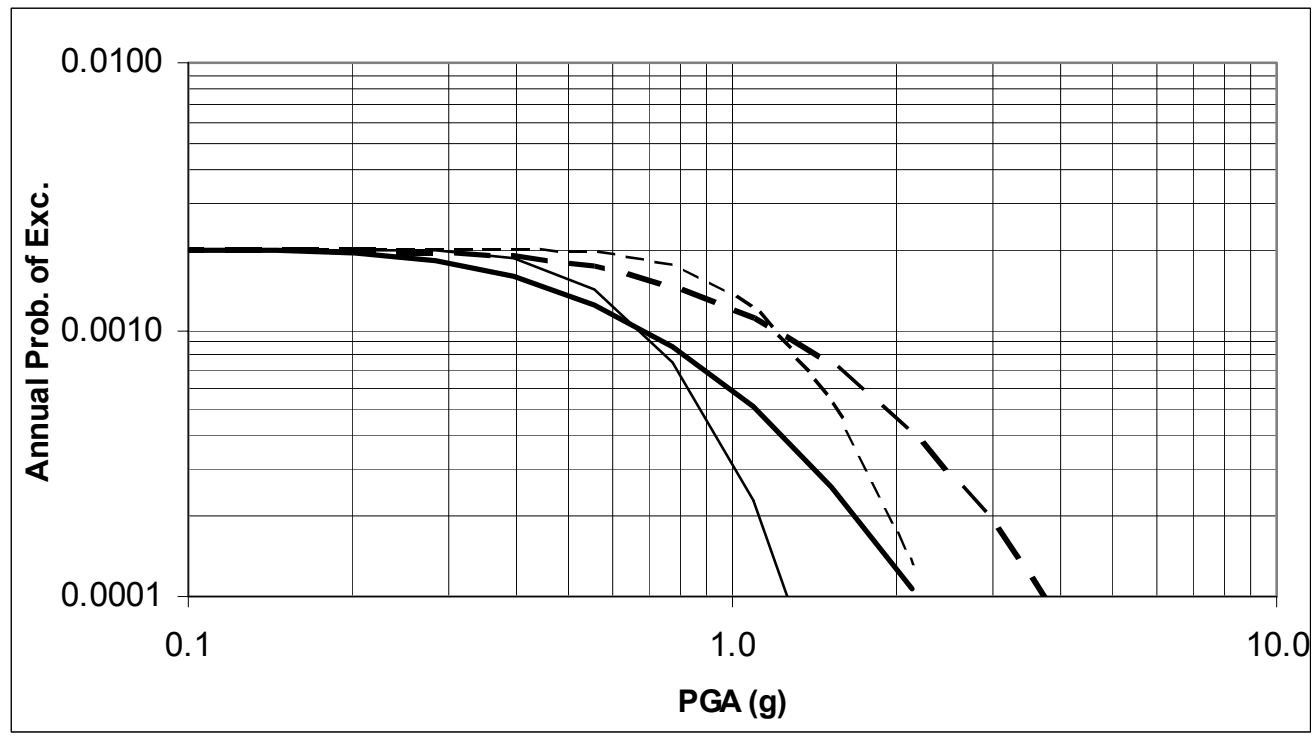

Figure 2. Comparison of hazard curves for median PGAs of 1.20 and $0.69 \mathrm{~g}$ and standard deviations of 0.38 and 0.7. Solid lines are for a median PGA of $0.69 \mathrm{~g}$ with 0.38 (light) and 0.7 standard deviations (heavy). Dashed lines are for a median PGA of $1.20 \mathrm{~g}$ with 0.38 (light) and 0.7 standard deviations (heavy).

The standard deviations used in the USGS national seismic hazard maps are 0.75 for both PGA and 5.0 Hz S.A., and 0.8 for 1.0 Hz S.A. (Frankel et al., 1996, 2002). Figure 3 shows hazard curves for San Francisco (N37.8/W122.4) (long dashed line) and LaCenter, 
Ky. (N37.1/W89.0) (short dashed line) from the 2002 USGS national seismic hazard maps (Frankel et al., 2002). Higher standard deviations predict even higher hazards at the low annual probability of exceedance in the New Madrid area than in San Francisco.

Also shown in Figure 3 are hazard curves for the median ground motion of Sommerville et al. (2001) at $15 \mathrm{~km}$ distance with standard deviations of 0.38 (light solid line) and 0.7 (heavy solid line). Even though the median $1.0 \mathrm{~Hz}$ S.A.(0.37g) in the New Madrid is lower than that $(0.41 \mathrm{~g})$ in San Francisco, $1.0 \mathrm{~Hz}$ S.A hazards at the low annual probability of exceedance are quite similar for the higher standard deviation (0.7)(Fig. $3 \mathbf{c})$.

From these comparisons, one could conclude that the higher ground motion uncertainties (both median and its standard deviation), higher standard deviation in particular, cause the predicted higher hazards at low annual probability of exceedance $(<0.002)$ in the New Madrid area. A similar conclusion was also drawn by Cramer (2001) and Newman et al. (2001). However, Frankel (2004) compared the hazards at the low annual probability of exceedance between San Francisco and the New Madrid using an assumed standard deviation (0.38) for the New Madrid seismic zone and drew his conclusion. His conclusion is not necessary true and could cause confusion, especially among nonpractitioners. Hence, instead of his statement "it is a consequence of the higher ground motion (median)," it would be more accurate to say "it is a consequence of the higher ground motion uncertainties (both median and its standard deviation)." 

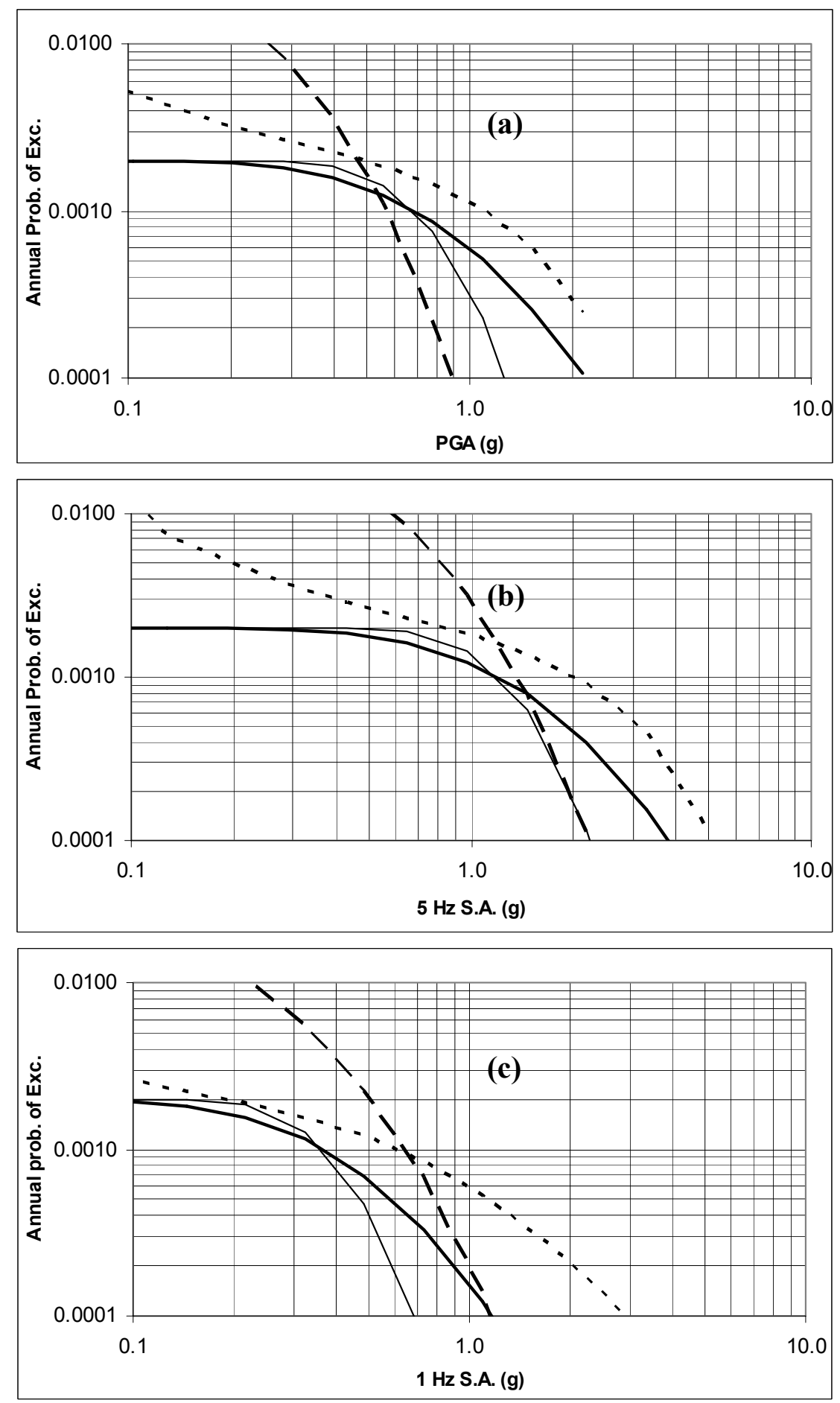

Figure 3. Hazard comparisons between San Francisco (N37.8/W122.4) (long dashed line) and LaCenter, Ky. (N37.1/W89.0) (short dashed line) from the 2002 National seismic hazard maps (Frankel et al., 2002). Also shown are hazard curves for the New Madrid characteristic earthquake (M7.7) at a site $15 \mathrm{~km}$ distance using Sommerville et al.(2001) attenuation relationship (solid line) with standard deviations of 0.38 and 0.7. (a) is for PGA hazard, (b) for $5 \mathrm{~Hz}$ S.A. hazard, and (c) for $1 \mathrm{~Hz}$ S.A. hazard. 


\section{What Are the 10, 5, 2\% PE in 50 Years?}

If earthquake recurrence is time-independent and independent of the history of previous earthquakes, a Poisson model (Cornell, 1968, Stein and Wysession, 2003) predicts that the probability of $n$ events (earthquakes) of given size in an area or along a fault during a time interval of $t$ years is

$$
p(n, t, \tau)=\frac{e^{-t / \tau}(t / \tau)^{n}}{n !},
$$

where $\tau$ is the average occurrence time (or average occurrence rate, $1 / \tau$ ) of the earthquake. The probability that no earthquake occurs is thus

$$
p(0, t, \tau)=e^{-t / \tau}
$$

And the probability of one or more earthquakes is

$$
p(n \geq 1, t, \tau)=1-p(0, t, \tau)=1-e^{-t / \tau} \approx 1-(1-1 / \tau)^{t} .
$$

Equation (4) has been widely used to calculate risk level (X \% PE in Y years) for a given average occurrence time $(\tau)$ of the event (earthquake, flood, wind) or average occurrence time $(\tau)$ for a given risk level in engineering risk analysis (Cornell, 1968; Sachs, 1978; Gupta, 1989; ICC, 2000). For example, $1 \% \mathrm{PE}$ in one year is commonly used risk level in building design for flood hazard, and $2 \%$ PE in one year for wind hazard (ICC, 2000). From equation (4), the average occurrence time of the flood corresponding to the $1 \% \mathrm{PE}$ in one year is 100 years (100-year-flood), and the average occurrence time of the 3-s gust-wind corresponding to the $2 \% \mathrm{PE}$ in one is 50 years. 10,5 , and $2 \% \mathrm{PE}$ in 50 years risk levels are commonly used in earthquake engineering (BSSC, 1998; ICC, 2000). The average occurrence times of the earthquakes corresponding to the 10, 5 , and $2 \% \mathrm{PE}$ in 50 year are 500,1,000, and 2,500 years, respectively. Hence, the risks, 10, 5, and $2 \%$ PE in 50 years, mean that the rare earthquakes will occur one or more (at least once) in 500, 1,000 , and 2,500 years, respectively.

Although equation (4) is used to predict a rare earthquake, it can also be used to predict the physical measurements, such as Modified Mercalli Intensity (MMI) and ground motion, that could be generated by the earthquake at a point of interest through the attenuation relationships (Cornell, 1968). For example, Campbell (2003) found that PGA follows the relationship of

$$
\begin{aligned}
\ln (P G A)= & 0.0305+0.633 M-0.0427(8.5-M)^{2}-1.591 \ln R \\
& +(-0.00428+0.000483 M) r_{r u p}
\end{aligned}
$$

where

$$
R=\sqrt{r_{\text {rup }}^{2}+[0.683 \exp (0.416 M)]^{2}},
$$


$\mathrm{r}_{\mathrm{rup}} \leq 70 \mathrm{~km}$, and $\sigma_{\operatorname{lnPGA}}=0.414$ (aleatory standard deviation for $\mathrm{M} \geq 7.16$ ). For the New Madrid characteristic earthquake of M7.7, we have

$$
\begin{array}{r}
\ln (P G A)=4.87727-1.591 \ln R-0.000561 r_{r u p}, \\
R=\sqrt{r_{r u p}^{2}+16.8^{2}},
\end{array}
$$

and the total $\sigma_{\ln }=0.689$.

In the New Madrid area, there is only one rare earthquake, the characteristics earthquake of M7.7 with the average recurrence time of 500 years (i.e. $T c=\tau=500 \mathrm{yr}$.). Therefore, there is only one risk level, $10 \%$ PE in 50 years, to be considered in the New Madrid area. The PGAs with the risk level of 10\% PE in 50 years are listed in Table 2 using Campbell (2003) attenuation relationship.

Table 2. PGAs with $10 \%$ PE in 50 years risk level in the New Madrid area.

\begin{tabular}{|c|c|c|c|}
\hline $\mathrm{r}_{\text {rup }}(\mathrm{km})$ & 20 & 40 & 60 \\
\hline Median $(50 \%$ confidence $)$ & $0.72 \mathrm{~g}$ & $0.32 \mathrm{~g}$ & $0.18 \mathrm{~g}$ \\
\hline Median $+1 \sigma_{\operatorname{lnPGA}}(84 \%$ confidence $)$ & $1.43 \mathrm{~g}$ & $0.64 \mathrm{~g}$ & $0.35 \mathrm{~g}$ \\
\hline Median $+2 \sigma_{\operatorname{lnPGA}}(98 \%$ confidence $)$ & $2.86 \mathrm{~g}$ & $1.27 \mathrm{~g}$ & $0.71 \mathrm{~g}$ \\
\hline
\end{tabular}

Hence, the average occurrence rate $(1 / \tau)$ of a rare earthquake derived from the risk analysis is fundamentally different from the annual probability of exceedance $(\gamma)$ derived from PSHA. In the New Madrid seismic zone, the average occurrence rate of the characteristic earthquake is only one, $0.002(1 / 500 \mathrm{yr}$.), whereas the annual probabilities of exceedance are many and equal to the average occurrence rate (0.002) times the probability that ground motion exceeds the corresponding value. Frankel (2004) equated the average occurrence rate from the risk analysis with the annual probability of exceedance from PSHA, however. Equating the average occurrence rate with the annual probability of exceedance is not appropriate and causes confusion.

\section{Summary}

PSHA is the most used method to assess seismic hazards for input into various aspects of public and financial policy. For example, PSHA was used by the U.S. Geological Survey to develop the national seismic hazard maps (Frankel et al., 1996, 2002). These maps are the basis for many national, state, and local seismic safety regulations and design standards, such as the NEHRP Recommended Provisions for Seismic Regulations for New Buildings and Other Structures, the International Building Code, and the International Residential Code. Adoption and implementation of these regulations and design standards would have significant impacts on many communities in the New Madrid area, including Memphis, TN and Paducah, KY. Although "mitigating risks to society from earthquakes involves economic and policy issues" (Stein, 2004), seismic hazard assessment is the basis. Seismologists should provide the best information on 
seismic hazards and communicate them to the users and policy makers. However, there is a lack of effort in communicating the uncertainties in seismic hazard assessment in the central US. Use of 10,5 , and $2 \%$ PE in 50 years causes confusion in communicating seismic hazard assessment. It would be easy to discuss and understand the design ground motions if the true meaning of the ground motion derived from PSHA is presented, i.e. the ground motion with the estimated uncertainty or the associated confidence level.

\section{Reference}

Abrahamson, N.A. and W.J. Silva, 1997, Empirical response spectral attenuation relations for shallow crustal earthquakes, Seis. Res. Lett., 68:94-127.

Atkinson, G. M. and D. M. Boore, 1995, Ground motion relations for eastern North America, Bull. Seismo. Soc. Am., 85:17-30.

Boore, D.M., W.B. Joyner, and T.E. Fumal, 1997, Equations for estimating horizontal response spectra and peak acceleration from western North American earthquakes: A summary of recent work, Seis. Res. Lett., 68:128-153.

Building Seismic Safety Council (BSSC), 1998, NEHRP recommended provisions for seismic regulations for new buildings [1997 ed.]: Federal Emergency Management Agency, FEMA 302, 337 p.

Campbell, K W., 2003, Prediction of strong ground motion using the hybrid empirical method and its use in the development of ground-motion (attenuation) relations in eastern North America, Bull. Seismo. Soc. Am., 93:1,012- 1,033.

Campbell, K.W., 1981, Near-source attenuation of peak horizontal acceleration, Bull. Seismo. Soc. Am., 71:2,039- 2,070.

Campbell, K.W. and Y. Bozorgnia, 2003, Updated near-source ground motion (attenuation) relations for the horizontal and vertical components of peak ground acceleration and acceleration response spectra, Bull. Seismo. Soc. Am., 93:314331.

Cornell, C.A., 1968, Engineeing seismic risk analysis, Bull. Seismo. Soc. Am., 58:1,5831,606 .

Cramer, C. H., 2001, The New Madrid seismic zone: capturing variability in seismic hazard analyses, Seis. Res. Lett., 72:664-672.

EPRI (Electric Power Research Institute), 2003, CEUS ground motion project, model development and results, report \#1008910, EPRI, Palo Alto, CA.

Frankel, A., 2004, How can seismic hazard around the New Madrid seismic zone be similar to that in California?, Seis. Res. Lett., 75:575-586.

Frankel, A. D., M. D. Petersen, C. S. Mueller, K. M. Haller, R. L. Wheeler, E.V. Leyendecker, R. L. Wesson, S. C. Harmsen, C. H. Cramer, D. M. Perkins, and K. S. Rukstales, 2002, Documentation for the 2002 Update of the National Seismic Hazard Maps, U.S. Geological Survey Open-File Report 02-420, 33p.

Frankel, A., C. Mueller, T. Barnhard, D. Perkins, E. Leyendecker, N. Dickman, S. Hanson, and M. hopper, 1996, National Seismic Hazard Maps: Documentation June 1996, U.S. Geological Survey Open-file Repoart 96-532, 110p.

Gupta, R.S. (1989), Hydrology and Hydraulic System, Prentice Hall, Englewood Cliffs, New Jersey. 
Harmsen, S., Perkins, D., and Frankel, A., 1999, Deaggregation of probabilistic ground motions in the central and eastern United States: Bull. Seism. Soc. Am., 89:1-13.

ICC (International Code Council), 2000, International Building Code, International Code Council, Inc.

Joyner, W.B. and D.M. Boore, 1982, Prediction of earthquake response spectra, U.S. Geological Survey Open-File Report 82-977.

Newman, A., J. Schneider, S. Stein, and A. Mendez, 2001, Uncertainties in seismic hazard maps for the New Madrid seismic zone and implications for seismic hazard communication, Seis. Res. Lett., 72:647-663.

Sachs, P., 1978, Wind forces in engineering, $2^{\text {nd }}$ Edition, Pergamon Press Inc., Elmsford, NY.

Sadigh, K., C. Y. Chang, J. Egan, F. Makdisi, and R. Youngs, 1997, Attenuation relationships for shallow crustal earthquakes based on California strong motion data, Seis. Res. Lett., 68:180-189.

Senior Seismic Hazard Analysis Committee (SSHAC), 1997, Recommendations for probabilistic seismic hazard analysis: Guidance on uncertainty and use of experts: Lawrence Livermore National Laboratory, NUREG/CR-6372, 81 p.

Somerville, P., N. Collins, N. Abrahamson, R. Graves, and C. Saikia, 2001, Ground motion attenuation relations for the central and eastern United States, final report to U.S. Geological Survey.

Stein, S., 2004, No Free Lunch, Seis. Res. Lett., 75:555-556.

Stein, S. and M. Wysession, 2003, an Introduction to Seismology, Earthquakes, and Earth Structure, Blackwell Publishing, Maldem, MA.

Toro, G. R., N. A. Abrahamson, and J. F. Schneider, 1997, Model of strong ground motions from earthquakes in central and eastern North America: best estimates and uncertainties, Seis. Res. Lett., 68:41-57.

Tuttle, M.P., E.S. Schweig, J.D. sims, R.H. Lafferty, L.W. Wolf, and M.L. Haynes, 2002, The earthquake potential of the New Madrid seismic zone, Bull. Seismo. Soc. Am., 92:2,080-2,089. 